\title{
Pancreatic Acinar Cell Carcinoma
}

National Cancer Institute

\section{Source}

National Cancer Institute. Pancreatic Acinar Cell Carcinoma. NCI Thesaurus. Code C7977.

An adenocarcinoma arising from the pancreas. It is characterized by the presence of relatively uniform malignant cells which form acinar patterns. It usually occurs during adulthood. Signs and symptoms include abdominal pain, weight loss, nausea, and diarrhea. It may metastasize to regional lymph nodes and the liver. A minority of patients develop lipase hypersecretion syndrome. This syndrome may be seen in patients with liver metastases and it is characterized by excessive secretion of lipase in the serum, polyarthralgia, and subcutaneous fat necrosis. 